\title{
REKONSTRUKSI PENYELESAIAN SENGKETA ADMINISTRASI DAN HASIL PEMILIHAN GUBERNUR, BUPATI DAN WALIKOTA
}

\author{
Much. Anam Rifai \\ Komisi Pemilihan Umum Kabupaten Tulungagung \\ J1. KHR. Abdul Fatah IV/3 Tulungagung \\ Email: anamrifai@gmail.com
}

\begin{abstract}
Administrative dispute resolution, as well as results in elections for governor, regent and mayor today, may raise many legal issues. Some of such issues are the State Administrative Court's inexecutable decision's, the decision's contradicting dualism and legal disharmony during stages of election. These problematic issues can lead to legal uncertainty, public confusion as well as potency for horizontal conflict. Therefore, an immediate recontruction of both administrative dispute resolution and results in election for governor, regent and mayor needs to be conducted. Through the prespective of normative legal study, it is concluded that in the future, there should be readjustments of stages in elections for governor, regent, and mayor by regarding the time constraints to solve any matter of dispute within the legal boundaries of Election Supervisory Board at provincial an regencial level or State Administrative Court's, as well as reevaluations in authorizing other form of legal institutions to solve any dispute regarding the elections results.
\end{abstract}

Key words: reconstruction, administrative dispute and results in elections for governor, regent and mayor, elections for governor, regent and mayorelection

\begin{abstract}
Abstrak
Penyelesaian sengketa administrasi dan hasil pemilihan gubernur, bupati dan walikota yang selama ini sudah dilaksanakan menimbulkan banyak permasalahan hukum. Beberapa di antaranya adanya putusan PTUN yang tidak bisa dieksekusi, dualisme putusan badan peradilan yang saling bertentangan serta disharmonisasi hukum acara PTUN dengan tahapan pemilihan. Permasalahan tersebut menyebabkan terjadinya ketidakpastian hukum, kebingungan masyarakat, serta berpotensi menimbulkan konflik horizontal. Oleh sebab itu rekonstruksi sistem penyelesaian sengketa administrasi dan hasil pemilihan gubernur, bupati dan walikota mutlak dilakukan. Melalui penelitian hukum normatif disimpulkan, ke depan harus ada penyusunan ulang tahapan pemilihan gubernur, bupati dan walikota dengan memperhatikan limitasi waktu penyelesaian sengketa di Bawaslu provinsi/Panwaslu Kabupaten/Kota maupun di PTUN, serta melakukan peninjauan kembali pengaturan pemberian wewenang kepada badan peradilan selain Peradilan Tata Usaha Negara untuk menyelesaikan sengketa hasil pemilihan gubernur, bupati dan walikota.
\end{abstract}

Kata kunci: rekonstruksi, sengketa administrasi dan hasil pemilihan gubernur, bupati dan walikota, pemilihan gubernur, bupati dan walikota 


\section{Latar Belakang}

PemilihanUmum Kepala Daerah dan Wakil Kepala Daerah (Pemilukada) ${ }^{1}$ secara langsung mulai dilaksanakan pada Tahun $2005 .^{2}$ Sistem ini lahir sejak UU No. 32 Tahun 2004 tentang Pemerintahan Daerah diundangkan tanggal 15 Oktober 2004. Pemilukada langsung menggantikan Pemilihan Kepala Daerah dan Wakil Kepala Daerah yang dilaksanakan oleh Dewan Perwakilan Rakyat Daerah. ${ }^{3}$ Pada pelaksanaannya, Pemilukada melahirkan banyak permasalahan, baik dari segi kerangka pemahaman peraturan hukum, kesiapan lembaga penyelenggara, kesiapan partai politik, dan kesiapan masyarakat. UU No. 32 Tahun 2004 sebagaimana telah diubah dengan UU No. 12 Tahun 2008 sebagai aturan induk masih sangat lemah sehingga kerapkali pasal atau ayatnya dibatalkan oleh Mahkamah Konstitusi ${ }^{4}$ pada saat ada judicial review.
Pada programlegislasinasional(prolegnas) RUU prioritas Tahun 2014, DPR memutuskan untuk memisah pengaturan pemilihan kepala daerah dan wakil kepala daerah dari Undangundang Pemerintah Daerah. ${ }^{5}$ Tanggal 30 September 2014 disahkan UU No. 23 tentang Pemerintahan Daerah. Tahun yang sama, tanggal 30 September 2014 disahkan UU No. 22 Tahun 2014 tentang Pemilihan Gubernur, Bupati dan Walikota. UU No. 22 Tahun 2014 mengubah sistem pemilihan gubernur, bupati dan walikota dari dipilih langsung oleh rakyat menjadi dipilih oleh DPRD. Belum sempat dilaksanakan, UU No. 22 Tahun 2014 dicabut dan dinyatakan tidak berlaku dengan Peraturan Pemerintah Pengganti Undangundang No. 1 Tahun 2014 tentang Pemilihan Gubernur, Bupati dan Walikota. Perppu tersebut mengatur pemilihan gubernur, bupati dan walikota kembali dipilih secara langsung.

$1 \quad$ Istilah Pemilukada diatur dalam UU No. 22 Tahun 2007 tentang Penyelenggara Pemilihan Umum. Istilah ini berganti menjadi Pemilihan Gubernur, Bupati dan Walikota sebagaimana diatur dalam UU No. 15 Tahun 2011 tentang Penyelenggara Pemilihan Umum. UU No. 15 Tahun 2011 menghilangkan kalimat pemilihan umum. Penghilangan kalimat pemilihan umum diperkuat dengan Putusan MK Nomor 97/PUU-XI/2013 yang menyatakan Pemilihan Gubernur, Bupati dan Walikota bukanlah bagian dari pemilihan umum. UU No 1 Tahun 2015 menegaskan UU No. 15 Tahun 2011 terkait penggunaan istilah Pemilihan Gubernur, Bupati dan Walikota. Jadi dalam tulisan ini perbedaan penggunaan istilah pemilihan kepala daerah dan wakil kepala daerah (Pilkada), Pemilukada dan Pemilihan Gubernur, Bupati dan Walikota oleh penulis sesungguhnya merujuk pada maksud yang sama. Penulis memahami sebenarnya penggunaan masing-masing istilah tersebut memiliki konsekwensi hukum yang berbeda-beda. Namun di era transisi regulasi saat ini, pencampuran penggunaan istilah sulit untuk dihindari. Apalagi hasil revisi UU No. 1 Tahun 2015 yang sudah disepakati Komisi II DPR mengembalikan lagi pemilihan satu paket kepala daerah dan wakil kepala daerah. Sebelumnya dalam UU No. 1 Tahun 2015 yang dipilih hanya gubernur, bupati dan walikota.

2 Pemilukada secara langsung pertama kali diadakan pada tanggal 1 Juni 2005 di Kabupaten Kutai Kertanegara Provinsi Kalimantan Timur.

3 Kepala daerah dan wakil kepala daerah dipilih oleh DPRD pernah diatur dalam Pasal 39 ayat (1) UndangundangNo 22 Tahun 1999 tentang Pemerintahan Daerah.

4 Data yang disampaikan Arif Wibowo Anggota Komisi II DPR-RI menyebutkan, pengujian UU No 32 Tahun 2004 beserta perubahannya ke Mahkamah Konstitusi sudah dilakukan sebanyak 36 kali/perkara (data terakhir Februari 2012). 6 di antaranya dikabulkan, 3 ditarik kembali, dan 27 dinyatakan tidak diterima atau ditolak. Achmad Dodi Hermanto (ed), Demokrasi Lokal, Evaluasi Pemilukada di Indonesia, KONpress, Jakarta, 2012, hlm. 102-103.

5 Keputusan Dewan Perwakilan Rakyat Republik Indonesia Nomor: 03A/DPR RI/II/2013-2014 tentang Program Legislasi Nasional Rancangan Undang-undang Prioritas Tahun 2014 tanggal 17 Desember 2013. 
Melalui UU No. 1 Tahun 2015, Peraturan Pemerintah Pengganti Undang-undang No. 1 Tahun 2014 ditetapkan menjadi undangundang.

Riset Perkumpulan untuk Pemilu dan Demokrasi (Perludem) menyimpulkan, ${ }^{6}$ permasalahan dalam kerangka hukum pada penyelenggaraan Pemilukada Tahun 2005 sampai dengan 2014 menimbulkan kesimpangsiuran dan ketidakjelasan bagi penyelenggara maupun peserta Pemilukada. Peraturan yang ambigu serta multitafsir berkontribusi pada rentetan persoalan dalam penyelenggarakan tahapan Pemilukada, sebut saja masalah daftar pemilih, kisruh pencalonan, kampanye yang tidak terkontrol, pemungutan dan penghitungan suara yang bermasalah hingga terjadinya konflik horizontal antar masyarakat. Jika dianatomi, beberapa konflik horizontal dalam Pemilukada disebabkan dua hal. ${ }^{7}$ Pertama, adanya rasa ketidakpuasan dari pasangan calon atau pendukung pasangan calon ketika pasangan calon gugur dalam tahap pencalonan. Kedua, adanya rasa ketidakpuasan pasangan calon terhadap hasil penghitungan Pemilukada.

Sebenarnya Negara sudah menyiapkan beberapa model penyelesaian sengketa Pemilukada yang diatur dalam UU terkait. Pertama, penyelesaian sengketa yang berkaitan dengan penetapan hasil Pemilukada menjadi kewenangan Mahkamah Konstitusi. Dalam perkembangan, pada tanggal 19 Mei 2014 melalui Putusan Nomor 97/PUU-XI/2013, Mahkamah Konstitusi menyatakan tidak lagi memiliki kewenangan untuk menyelesaikan sengketa hasil penghitungan suara pemilihan kepala daerah dan wakil kepala daerah. Selanjutnya dalam UU No. 1 Tahun 2015 kewenangan penyelesaian sengketa hasil Pemilihan Gubernur, Bupati dan Walikota diberikan kepada Mahkamah Agung. Hasil revisi terbatas UU No.1 Tahun 2015, wewenang penyelesaian sengketa hasil Pemilihan Gubernur, Bupati dan Walikota diserahkan kembali ke Mahkamah Konstitusi sebelum dibentuk badan peradilan khusus yang menyelesaikan sengketa hasil Pemilihan Gubernur, Bupati dan Walikota. ${ }^{8}$

Kedua, penyelesaian sengketa pelanggaran Pemilukada baik yang dilakukan Komisi Pemilihan Umum maupun Peserta Pemilukada menjadi kewenangan Bawaslu Provinsi atau Panwaslu Kabupaten/Kota. Ketiga, terhadap sengketa Pemilukada yang bersumber dari Keputusan Komisi Pemilihan Umum yang mengandung unsur keputusan tata usaha Negara dan tidak terkait dengan hasil Pemilukada menjadi kewenangan Peradilan Tata Usaha Negara (PTUN). ${ }^{9} \quad$ Keempat,

6 Titi Angraini dkk, Menata Kembali Pengaturan Pemilukada, Perludem, Jakarta, 2011, hlm. Kata Pengantar iv.

$7 \quad$ Ibid., hlm. 21.

8 Pada saat jurnai ini ditulis, revisi tersebut belum dituangkan dalam bentuk UU tentang Perubahan UU No. 1 Tahun 2015. Meskipun begitu, peralihan kembali kewenangan penyelesaian sengketa hasil pemilihan dari MA ke MK sudah menjadi kesepakatan Anggota Komisi II DPR RI.

9 Pasal 2 UU No. 5 Tahun 1986 tentang Peradilan Tata Usaha Negara Sebagaimana Telah Diubah Terkahir dengan UU No. 51 Tahun 2009. 
terhadap dugaan adanya pelanggaran kode etik yang dilakukan unsur penyelenggara Pemilu diselesaikan oleh DKPP.

Pada prakteknya, model penyelesaian sengketa Pemilukada yang dilakukan di beberapa lembaga Negara yang berbeda termasuk di dalamnya sengketa administrasi dan hasil Pemilukada menimbulkan banyak masalah. Di beberapa daerah seperti Kota Depok, Kabupaten Timor Tengah Utara, maupun Kabupaten Lombok Tengah, Putusan Peradilan Tata Usaha Negara sudah melewati tahapan proses penyelesaian perselisihan hasil Pemilukada di Mahkamah Konstitusi. Ada juga putusan Peradilan Tata Usaha Negara yang sudah melewati proses tahapan pelantikan kepala daerah dan wakil kepala daerah terpilih. Akibatnya Komisi Pemilihan Umum sebagai pihak tergugat maupun Kementerian Dalam Negeri sebagai pihak yang ikut terkait dengan putusan tersebut kesulitan bahkan tidak bisa melaksanakan putusan Peradilan Tata Usaha Negara.

Masalah selanjutnya adalah adanya dualisme putusan pengadilan yang berbeda yakni antara Putusan PTUN dengan Putusan Mahkamah Konstitusi. Sebagai lembaga peradilan yang diberikan kewenangan untuk menyelesaikan perselisihan hasil Pemilukada, Mahkamah Konstitusi menolak penafsiran bila hanya memiliki kewenangan untuk menyelesaikan perselisihan yang terkait hasil saja yakni hasil hitung-hitungan secara angka penghitungan dan rekapitulasi pemungutan suara. Achmad Sodiki ${ }^{10}$ menjelaskan, Mahkamah Konstitusi memaknai Pemilukada adalah rangkaian proses yang dimulai dari tahapan persiapan, pelaksanaan dan tahap akhir yang membuahkan suatu hasil Pemilukada. Berangkat dari pemikiran tersebut, Mahkamah Konstitusi memperluas penafsiran tentang kewenangan menyelesaikan perselisihan hasil Pemilukada termasuk juga mengadili proses-proses Pemilukada termasuk proses pencalonan, pemutakhiran daftar pemilih, pelanggaran pada saat kampanye, money politik, intimidasi, keterlibatan birokrasi, dan lain sebagainya.

Di sisi lain putusan berbeda dapat dikeluarkan oleh Pengadilan Tata Usaha Negara meskipun Mahkamah Konstitusi sudah menilai proses secara keseluruhan pelaksanaan Pemilukada sudah berjalan sesuai dengan asas-asas kepemiluan dan peraturan perundang-undangan. Pengadilan Tata Usaha Negara dapat berpendapat lain dengan membuat putusan yang menyatakan batal salah satu keputusan yang dibuat oleh Komisi Pemilihan Umum apabila ada gugatan ke Pengadilan Tata Usaha Negara. Fakta tersebut terjadi pada Pemilukada Kabupaten Lombok Tengah Tahun 2010.

Dari gambaran fakta-fakta penyelesaian sengketa Pemilukada yang terjadi di atas, sesungguhnya ada kekurangtepatan dalam konstruksi peraturan perundang-undangan yang mengatur penyelesaian sengketa Pemilukada sehingga berdampak adanya

10 Achmad Dodi Hermanto (ed), Op.cit., hlm. 39. 
ketidakpastian hukum, kebingungan penyelenggara Pemilu, serta pelanggaran terhadap hak-hak konstitusionalitas bakal calon atau calon peserta Pemilukada. Pengaturan penyelesaian sengketaadministrasi Pemilukada yang menjadi kewenangan PTUN tidak mengatur batas waktu penyelesaian sengketa. Kondisi itu membuka peluang terjadinya putusan diucapkan setelah melewati tahapan pemungutan suara maupun tahapan penyelesaian sengketa hasil Pemilukada di MahkamahKonstitusibahkansetelahpasangan kepala daerah dan wakil kepala daerah dilantik. Di sisi lain Mahkamah Konstitusi terikat oleh waktu untuk menyelesaikan sengketa hasil Pemilukada sehingga tidak bisa menunggu proses penyelesaian sengketa administrasi di PTUN sampai selesai. Begitu halnya dengan pemberian kewenangan penanganan pelanggaran administrasi kepada Bawaslu Provinsi dan Panwaslu Kabupaten/ Kota hanyalah bersifat rekomendasi sehingga membuka peluang KPU untuk tidak melaksanakannya.

Penulis menilai sumber problematika terhadap karut-marutnya sistem penyelesaian sengketa administrasi dan sengketa hasil Pemilukada yang selama ini terjadi sesungguhnya terletak pada pengaturan penyelesaian sengketa dalam peraturan perundang-undangan terkait yang tidak tepat. Pertanyaannya kemudian, apakah UU No. 1 Tahun 2015 yang sudah disahkan mampu menjawab persoalan-persoalan yang muncul dalam penyelesaian sengketa administrasi dan hasil pemilihan gubernur, bupati dan walikota? Dari situ penulis menilai ada dua isu permasalahan hukum yang dapat dikemukakan dalam tulisan ini. (1) apa permasalahan hukum yang muncul dari pengaturan penyelesaian sengketa administrasi dan hasil pemilihan gubernur, bupati dan walikota sebelum UU No. 1 Tahun 2015 berlaku? (2) bagaimana rekonstruksi penyelesaian sengketa administrasi dan hasil pemilihan gubernur, bupati dan walikota?

Untuk menjawab isu hukum tersebut digunakan metode penelitian hukum normatif (normative legal research). Pendekatan yang digunakan yakni pendekatan peraturan perundang-undangan (statute approach), pendekatan kasus (case approach), pendekatan konseptual (conceptual approach $)^{11}$ dan pendekatan komparatif. Pendekatan peraturan perundang-undangan (statute approach) digunakan berkaitan dengan pengaturan penyelesaian sengketa administrasi dan sengketa hasil Pemilihan Umum Kepala Daerah dan Wakil Kepala Daerah yang tertuang di dalam peraturan perundangundangan. Pendekatan ini digunakan untuk melihat ketepatan konstruksi pengaturan penyelesaian sengketa administrasi dan sengketa hasil Pemilihan Umum Kepala Daerah dan Wakil Kepala Daerah yang ada dalam peraturan perundang-undangan.

11 Peter Mahmud Marzuki, Penelitian Hukum, Kencana Prenada Media Group, Jakarta, 2012, hlm. 133. 
Pendekatan kasus (case approach) digunakan berkaitan dengan adanya putusan lembaga peradilan yang menimbulkan adanya ketidakpastian hukum dalam proses penyelesaian sengketa administrasi dan sengketa hasil Pemilihan Umum Kepala Daerah dan Wakil Kepala Daerah. Pendekatan ini digunakan untuk menganalisa beberapa putusan pengadilan yang terkait dengan penyelesaian sengketa administrasi dan hasil Pemilihan Umum Kepala Daerah dan Wakil Kepala Daerah. Pendekatan konseptual (conceptual approach) digunakan untuk menyusun konsep-konsep baru terkait sengketa administrasi dan hasil Pemilihan Umum Kepala Daerah dan Wakil Kepala Daerah. Dalam menyusun konsep-konsep baru, peneliti beranjak dari padangan dan doktrin-doktrin yang berkembang dalam ilmu hukum. Pendekatan komparatif digunakan untuk memperbandingkan hasil konstruksi penulis dengan konstruksi UU No. 1 Tahun 2015 yang sudah disahkan tanggal 2 Februari 2015. Perbandingan tersebut terkait penyelesaian sengketa administrasi dan hasil pemilihan gubernur, bupati dan walikota.

Sebagaimana lazimnya suatu penelitian hukum normatif, bahan hukum yang digunakan dalam tulisan ini ada tiga yakni bahan hukum primer, bahan hukum sekunder dan bahan tersier. (1) Bahan hukum primer terdiri dari UUD 1945, UU No 5 Tahun 1986 tentang tentang Peradilan Tata Usaha Negara sebagaimana telah diubah terakhir dengan UU No. 51 Tahun 2009, UU No. 32
Tahun 2004 tentang Pemerintahan Daerah sebagaimana telah diubah dengan UU No. 12 Tahun 2008, UU No. 15 Tahun 2011 tentang Penyelenggara Pemilihan Umum, UU No 1 Tahun 2015 tentang Penetapan Peraturan Pemerintah Pengganti Undang-undang Nomor 1 Tahun 2014 tentang Pemilihan Gubernur, Bupati dan Walikota Menjadi undang-undang, Peraturan Pemerintah No. 6 Tahun 2005 tentang Pemilihan, Pengesahan Pengangkatan dan Pemberhentian Kepala Daerah dan Wakil Kepala Daerah, Peraturan KPU Nomor 9 tahun 2010 tentang Pedoman Penyusunan Tahapan, Program dan Jadwal Penyelenggaraan Pemilihan Umum Kepala Daerah dan Wakil Kepal Daerah, Putusan Kasasi Nomor 14/K/TUN/2012 dalam perkara Pemilukada Kota Depok, Putusan PTUN Jakarta Nomor 146/G/2011/PTUN-JKT tentang pembatalan Keputusan Menteri Dalam Negeri yang mengangkat Bupati dan Wakil Bupati terpilih dalam Pemilukada Kabupaten Tapanuli Tengah, Putusan Mahkamah Konstitusi Nomor 199/PHPU.DVIII/2010, Nomor 200/PHPU.D-VIII/2010 dan 201/PHPU.D-VIII/2010 dalam perkara Pemilukada Kota Depok, Putusan Mahkamah Konstitusi Nomor 31/PHPU.D-IX/2011 dalam perkara Pemilukada Tapanuli Tengah dan Putusan Mahkamah Konstitusi Nomor 97/ PUU-XI/2013 dalam pengujian Pasal 236C UU No. 12 Tahun 2008. (2) Bahan hukum sekunder, terdiri dari buku-buku literatur, jurnal penelitian, artikel dari majalah dan internet, hasil penelitian, tesis dan disertasi, 
makalah-makalah, yang relevan dengan penelitian ini. (3). Bahan hukum tersier, terdiri dari ensklopedia, kamus hukum, kamus politik yang terkait dengan penelitian ini.

Teknik memperoleh bahan hukum dilakukan melalui beberapa tahap. (1). Melakukan inventarisasi bahan hukum yang dibutuhkan; (2). Mencari bahan hukum primer dengan cara penelusuran pustaka maupun penelusuran di internet; (3). Mencari bahan hukum dengan cara penelusuran pustaka dan internet terhadap bahan hukum sekunder buku-buku literatur, jurnal dan hasil penelitian, disertasi dan tesis; (4). Mencari bahan hukum tersier dengan cara penelusuran pustaka. Bahan hukum yang diperoleh dianalisa secara preskriptif analitis ${ }^{12}$ untuk menemukan ketidaktepatan konstruksi penyelesaian sengketa administrasi dan sengketa hasil Pemilihan Umum Kepala Daerah dan Wakil Kepala Daerah saat ini.

\section{Pembahasan}

A. Persoalan Hukum yang Muncul dari Pengaturan Penyelesaian Sengketa Administrasi dan Hasil Pemilihan Gubernur, Bupati dan Walikota sebelum UU No. 1 Tahun 2015 Berlaku

\section{Mepetnya tahapan Pemilukada}

Pemilukada menggunakan tiga tahapan yang meliputi tahapan persiapan, pelaksanaan dan penyelesaian. Untuk memudahkan pelaksanaan tiap-tiap tahapan, disusun jadwal secara rinci yang mengacu pada UU No. 32 Tahun 2004 juncto UU No. 12 Tahun 2008 dan Peraturan KPU No. 9 Tahun 2010. Tahapan Pemilukada dituangkan dalam Keputusan KPU provinsi untuk Pemilukada provinsi dan Keputusan KPU kabupaten/ kota untuk Pemilukada Kabupaten/Kota. ${ }^{13}$ Keputusan tersebut bersifat mengikat ke luar dan ke dalam. Bersifat mengikat keluar dalam artian keputusan tersebut mengikat KPU provinsi atau KPU kabupaten/kota sebagai penerbit keputusan. Sedangkan bersifat mengikat keluar, keputusan tersebut mengikat masyarakat, partai politik, calon peserta Pemilu, dan pihak terkait lainnya.

Tahapan, Program dan Jadwal Pemilukada yang ditetapkan KPU berpengaruh terhadap kapan sengketa administrasi dan hasil Pemilukada akan terjadi. Semakin mepetnya waktu antara tahapan yang berpeluang terjadinya sengketa administrasi dengan tahapan hari dan tanggal pemungutan suara atau tahapan penyelesaian perselisihan hasil Pemilukada, semakin terbuka peluang sengketa administrasi selesai setelah tahapan perselisihan hasil Pemilukada selesai dilakukan di Mahkamah Konstitusi.

12 Ibid., hlm. 41-42.

13 Ramlan Surbakti mengatakan, salah satu indikator Pemilu berintegritas adalah seluruh tahapan Pemilu dilaksanakan berdasarkan peraturan perundang-undangan yang berlaku serta kode etik penyelenggaraan Pemilu. Tahapan Pemilu secara teknis diatur oleh KPU. Pengaturan tahapan secara rinci dan teknis oleh KPU disebut sebagai electoral regulation. Roejito dan Titik Ariyati Winahyu (ed), Putih Hitam Pengadilan Khusus, Sekretariat Jenderal Komisi Yudisial, Jakarta, 2013, hlm. 49-50. 
Sebagai contoh pada pelaksanaan Pemilukada Kabupaten Tulungagung, KPU Kabupaten Tulungagung menetapan pasangan calon pada tanggal 4 Desember 2012. Pelaksanaan pemungutan suara dilaksanakan pada tanggal 31 Januari 2013. Rentang waktu antara penetapan pasangan calon dengan pelaksanaan pemungutan suara 58 hari (di bulatkan 2 bulan). Dengan tenggat waktu pengajuan gugatan ke PTUN selama 90 hari (3 bulan) semenjak keputusan diterima atau diumumkan, apabila terjadi sengketa tata usaha Negara sudah bisa dipastikan potensi yang terjadi adalah putusan Peradilan Tata Usaha Negara yang berkekuatan hukum tetap baru terjadi setelah tahapan pemungutan suara selesai dilaksanakan. ${ }^{14}$

\section{Disharmonisasi hukum acara PTUNdengantahapan Pemilukada}

Sebagai mekanisme penyelesaian sengketa tata usaha Negara yang tidak didesain secara khusus untuk penyelesaian sengketa tata usaha Negara Pemilukada, dapat dimengerti mengapa hukum acara peradilan tata usaha Negara tidak harmonis dengan tahapan Pemilukada. Berdasarkan UU No. 5 Tahun 1986 sebagaimana telah diubah dua kali dengan UU No. 9 Tahun 2004 dan UU No. 51 Tahun 2009, penyelesaian sengketa tata usaha Negara di Peradilan Tata Usaha
Negara memakan waktu yang lama agar bisa memperoleh kekuatan hukum tetap. Bahkan kapan keluarnya putusan yang memiliki kekuatan hukum tetap tidak dapat diprediksi (unpredictable) waktunya keluar. Sebaliknya tahapan Pemilukada dibatasi waktu hanya sekitar delapan bulan. ${ }^{15}$ Akibatnya tahapan Pemilukada sudah selesai, proses penyelesaian sengkata tata usaha Negara di Peradilan Tata Usaha Negara belum memperoleh kekuatan hukum tetap.

Hukum acara Peradilan Tata Usaha Negara saat ini memang mengenal hukum acara cepat. Namun dibukanya peluang untuk melakukan upaya hukum banding, kasasi hingga peninjauan kembali dalam hukum acara cepat membuka peluang penyelesaian sengketa tata usaha Negara berlarut-larut hingga baru memperoleh kekuatan hukum tetap setelah tahapan Pemilukada selesai.

\section{Disharmonisasi hukum acara perselisihan hasil Pemilukada dengan hukum acara PTUN}

Penyelesaian perselisihan hasil Pemilukada oleh UU No. 12 Tahun 2008 dibatasi hanya 14 hari. Batasan tersebut dapat dimaknai bahwa proses penyelesaian perselisihan hasil Pemilukada membutuhkan waktu yang cepat agar segera mempunyai kepastian hukum. Dengan begitu tidak terjadi

14 Keputusan Komisi Pemilihan Umum Kabupaten Tulungagung Nomor: 37/Kpts/KPU-Kab/014.329939/2012 tentang Perubahan Kedua atas Keputusan Komisi Pemilihan Umum Kabupaten Tulungagung Nomor: 02//Kpts/KPU-Kab/014.329939/2012 tentang Tahapan, Program dan Jadwal Penyelenggaraan Pemilihan Umum Bupati dan Wakil Bupati Tulungagung Tahun 2013.

15 Peraturan KPU No. 9 Tahun 2010 tentang Tahapan, Program dan Jadwal Pemilihan Kepala Daerah dan Wakil Kepala Daerah. 
kekosongan pemerintahan yang berpotensi menimbulkan konflik politik. Tenggat waktu pengajuan permohonan perselisihan hasil Pemilukada dibatasi paling lambat 3 (tiga) hari kerja setelah KPU provinsi atau KPU kabupaten/kota menetapkan hasil perolehan suara Pemilukada. Permohonan yang diajukan melewati 3 (tiga) hari kerja setelah perolehan suara Pemilukada tidak dapat diregistrasi. ${ }^{16}$

Singkatnya waktupersidangan perselisihan hasil Pemilukada memaksa Mahkamah Konstitusi tidak bisa menunggu selesainya sengketa tata usaha Negara Pemilukada. Pada perkara-perkara tertentu, Mahkamah Konstitusi tidak menjadikan pertimbangan belum selesainya sengketa tata usaha Negara Pemilukada untuk membuat putusan sela ${ }^{17}$ untuk menunggu putusan sengketa tata usaha Negara memiliki kekuatan hukum tetap. Sebab jika itu dilakukan akan memakan waktu cukup lama. Penyelesaian sengketa tata usaha Negara Pemilukada tidak dapat diprediksi waktunya (unpredictable) kapan bisa selesai. Dengan begitu siapa pasangan calon kepala daerah dan wakil kepala daerah terpilih belum bisa dipastikan dengan cepat yang berpotensi menimbulkan terjadinya kekosongan kekuasaaan.

Namun di lain pihak dalam perkaraperkara Pemilukada tertentu, putusan sengketa tata usaha Negara yang telah memperoleh kekuatan hukum tetap atau belum berkekuatan hukum tetap dijadikan pertimbangan hukum oleh Mahkamah Konstitusi dalam membuat putusan. Mahkamah Konstitusi berpendapat, terdapat dalam beberapa perkara Pemilukada KPU provinsi atau KPU kabupaten/kota dengan sengaja mengabaikan putusan dari badan peradilan di mana KPU provinsi atau KPU kabupaten/kota memiliki kesempatan untuk melaksanakannya. Untuk perkara yang masih belum memiliki kekuatan hukum tetap, namun Mahkamah Konstitusi menemukan indikasi bahwa KPU provinsi atau KPU kabupaten/kota sengaja melakukan upaya hukum banding atau kasasi agar proses penyelesaian sengketa belum memiliki kekuatan hukum tetap, Mahkamah Konstitusi tetap menjadikan putusan badan peradilan tersebut sebagai salah satu pertimbangan hukum. ${ }^{18}$

\section{Putusan PTUN tidak bisa dieksekusi}

Persoalan hukum lain yang muncul dari mekanisme penyelesaian sengketa Tata Usaha Negara Pemilukada yang diatur dalam peraturan perundang-undangan sebelum UU No. 1 Tahun 2015 berlaku adalah adanya putusan Peradilan Tata Usaha Negara yang sudah memperoleh kekuatan hukum tetap

16 Peraturan Mahkamah Konstitusi No. 15 Tahun 2008 tentang Pedoman Beracara Perselisihan Hasil Pemilihan Kepala Daerah.

17 Maria Farida Indrati mengartikan putusan sela adalah putusan yang dijatuhkan oleh majelis hakim sebelum putusan akhir berupa putusan untuk melakukan atau tidak melakukan sesuatu berkaitan dengan objek yang dipersengketakan, Achmad Dodi Harmanto (ed), Op.cit., hlm. 65.

18 Lihat Putusan Nomor 115/PHPU.D-VIII/2010 tentang Perselisihan Hasil Pemilihan Umum Kepala Daerah dan Wakil Kepala Daerah Kabupaten Belitung Timur Tahun 2010. 
namun tidak dapat dieksekusi. Kenyataan itu menunjukan Negara gagal dalam menjalankan tugasnya dalam melakukan penegakan hukum. Agar lebih jelas, berikut dipaparkan contoh pelaksanaan Pemilukada di Kota Depok pada Tahun 2010.

Pemilukada Kota Depok Tahun 2010 diikuti oleh empat pasangan calon yakni H. Gagah Sunu Sumantri - Derry Drajat, H. Yuyun Wirasaputra - Pradi Supriatna, H. Nur Mahmudi Isma'il - KH. M. Idris Shomad, serta H. Drs. H. Badrul Kamal - H. A. Supriyanto. Persoalan muncul pada tahapan pencalonan dengan adanya dukungan ganda dari DPC Partai Hanura Kota Depok yang mendukung bakal pasangan calon H. Yuyun Wirasaputra, Pradi Supriatna dan bakal pasangan calon $\mathrm{H}$. Badrul Kamal - H. Supriyanto.

KPU Kota Depok menetapkan 4 (empat) pasangan calon yang memenuhi syarat sebagai peserta Pemilukada melalui Keputusan Komisi Pemilihan Umum Kota Depok No. 18/ Kpts/R/KPU-Kota/011.329181/2010 tanggal 24 Agustus 2010 tentang Penetapan Pasangan Calon dan Nomor Urut Pasangan Calon Walikota dan Wakil Walikota dalam Pemilihan Umum Walikota dan Wakil Walikota Depok Tahun 2010. Syamsul Marasabessy dan Wawan Ernawan selaku Plt. Ketua dan sekretrais Partai Hanura Kota Depok mengajukan gugatan terhadap keputusan tersebut ke PTUN Bandung. Melalui putusan Nomor 71/G/2010/ PTUN-BDG tanggal 15 Desember 2010, PTUN Bandung menyatakan batal Keputusan Komisi Pemilihan Umum Kota Depok No.
18/Kpts/R/KPU-Kota/011.329181/2010 dan memerintahkan kepada Komisi Pemilihan Umum Kota Depok untuk mencabut keputusan sebagaimana dimaksud.

KPU Kota Depok mengajukan banding ke PTTUN Jakarta, namun hasilnya ditolak. Tidak terima terhadap putusan PTTUN Jakarta, KPU Kota Depok mengajukan kasasi yang kemudian oleh Mahkamah Agung ditolak. Dengan terbitnya putusan kasasi tersebut, pembatalan Keputusan Komisi Pemilihan Umum Kota Depok No. 18/ Kpts/R/KPU-Kota/011.329181/2010 tentang Penetapan Pasangan Calon dan Nomor Urut Pasangan Calon Walikota dan Wakil Walikota dalam Pemilihan Umum Walikota dan Wakil Walikota Depok Tahun 2010 telah memperoleh kekuatan hukum tetap.

Sebagaimana amar putusan banding Pengadilan Tinggi Tata Usaha Jakarta yang sudah dikuatkan dengan putusan kasasi Mahkamah Agung, Komisi Pemilihan Umum Kota Depok diperintahkan untuk membatalkan dukungan Partai Hanura yang diberikan kepada dua pasangan calon atas nama H. Badrul Kamal dan H.A Supriyanto AT serta Yuyun Wirasaputra dan Pradi Supriatna. Akibat pembatalan dukungan tersebut, pasangan calon atas nama Yuyun Wirasaputra dan Pradi Supriatna tidak memenuhi syarat sebagai peserta Pemilukada karena dukungan gabungan partai politik kurang dari 15 persen suara sah hasil Pemilu 2009. Dampaknya peserta Pemilukada Kota Depok menjadi 3 pasangan calon. Persoalan menjadi rumit 
karena putusan Kasasi No. 14 K/TUN/2012 ditetapkan tanggal 06 Maret 2012. Padahal pemungutan suara Pemilukada Kota Depok dilaksanakan pada 16 Oktober $2010 .{ }^{19}$

\section{Putusan PTUN dan putusan MK berbeda}

Mekanisme penyelesaian sengketa admistrasi dan hasil Pemilukada yang diatur dalam peraturan perundang-undangan yang berlaku memunculkan adanya dua putusan lembaga peradilan yang berbeda. Berikut adalah contoh pelaksanaan Pemilukada di Tapanuli Tengah Tahun 2011 yang dapat dibaca melalui Putusan Mahkamah Konstitusi No. 31/PHPU.D-IX/2011 dan No. 32/ PHPU.D-IX/2011 serta Putusan PTUN Jakarta Nomor: 146/G/2011/PTUN-JKT.

Pemilukada Kabupaten Tapanuli Tengah Tahun 2011 diikuti oleh 3 pasangan calon yakni (1) Raja Bonaran Situmeang -H. Sukran Jamilan Tanjung, (2) Tasrif Tarihoran - Raja Asi Purba dan (3) Dina Riana Samosir Hikmal Batubara. Ada 2 bakal pasangan calon yang dinyatakan tidak memenuhi syarat sebagai peserta Pemilukada yakni bakal pasangan calon Albiner Sitompul-dr. Steven P.B. Simanungkalit serta bakal pasangan calon Muhamad Armand Effendy Pohan dan IHotben Bonar Gultom.

2 (dua) bakal pasangan calon yang dinyatakan tidak memenuhi syarat menggugat Keputusan Komisi Pemilihan Umum Kabupaten Tapanuli Tengah Nomor
730.A/KPU-T T/002.434687/XII/2010 tentang Penetapan Calon Bupati Kabupaten Tapanuli Tengah Tahun 2011 bertanggal 13 Desember 2010 ke Pengadilan Tata Usaha Negara Medan. 2 gugatan tersebut oleh Pengadilan Tata Usaha Negara Medan dikabulkan. Pengadilan Tata Usaha Negara Medan menyatakan batal Keputusan Komisi Pemilihan Umum Kabupaten Tapanuli Tengah Nomor 730/KPU-TT/002.434687/XII/2010 tentang Penetapan Calon Bupati dan Calon Wakil Bupati Kabupaten Tapanuli Tengah Tahun 2011. Pengadilan Tata Usaha Negara Medan selanjutnya memerintahkan Komisi Pemilihan Umum Kabupaten Tapanuli Tengah untuk mencabut Keputusan Komisi Pemilihan Umum Kabupaten Tapanuli Tengah Nomor 730/KPU-TT/002.434687/XII/2010. Putusan Pengadilan Tata Usaha Negara Medan telah berkekuatan hukum tetap pada 11 Juli 2011 seiring dengan adanya Penetapan Eksekusi dari Ketua Pengadilan Tata Usaha Negara Medan terhadap Putusan PTUN Medan Nomor: 01/G/2011/PTUN-MDN.

Pada saat perselisihan hasil Pemilukada di Mahkamah Konstitusi, Albiner Sitompul dan dr. Steven P.B. Simanungkalit mengajukan permohonan perselisihan hasil Pemilukada yang diiregister dalam perkara Nomor 31/ PHPU-IX/2011. Dalam perkara tersebut, Mahkamah Konstitusi menerbitkan putusan sela yang memerintahkan kepada Komisi Pemilihan Umum Kabupaten Tapanuli Tengah

19 Warga Antusias Ikuti Pilkada Depok, http://www.tempo.co/read/news/2010/10/16/057285132/WargaAntusias-Ikuti-Pilkada-Depok, diakses 16 April 2014 pukul 11.30 WIB. 
untuk melakukan verifikasi dan klarifikasi terhadap keempat bakal pasangan calon Pemilukada Kabupaten Tapanuli Tengah Tahun 2011 sebagai berikut:

1. Dina Riana Samosir dan Drs. Hikmal Batubara;

2. Albiner Sitompul dan dr. Steven P.B. Simanungkalit

3. Ir. Muhammad Armand Effendy Pohan dan Ir. Hotbaen Bonar Gultom, M.M.A;

4. Raja Bonaran Situmeang,S.H., M.Hum. dan H. Sukran Jamilan Tanjung, S.E.;

Putusan akhir Mahkamah Konstitusi yang tetapkan pada tanggal 22 Juni 2011 menyatakan Albiner Sitompul dan dr. Steven P.B. Simanungkalit tidak memenuhi syarat menjadi pasangan calon dalam Pemilihan Umum Kepala Daerah dan Wakil Kepala Daerah Kabupaten Tapanuli Tengah Tahun 2011.

Menyikapi adanya dua putusan yang berbeda antara Mahkamah Konstitusi dengan Pengadilan Tata Usaha Negara Medan perihal penetapan pasangan calon, ada beberapa pandangan hukum yang dapat disusun. Pertama dari sisi aturan perundang-undangan. Dilihat dari sisi ini sah-sah saja para hakim Mahkamah Konstitusi maupun Pengadilan Tata Usaha Negara menerbitkan dua putusan yang berbeda dalam kasus yang sama. Dua lembaga peradilan tersebut masing-masing memiliki wewenang untuk mengadili perkara yang diajukan kepada mereka dan memutus berdasarkan fakta-fakta hukum dan keyakinan yang mereka peroleh saat di persidangan.
Kedua, dari sisi daya ikat putusan. Baik putusan Mahkamah Konstitusi maupun Pengadilan Tata Usaha Negara mengikat para pihak yang bersengketa dan putusannya wajib dilaksanakan. Sebab, Mahkamah Konstitusi maupun Pengadilan Tata Usaha Negara adalah lembaga yang melaksanakan kekuasaan kehakiman yang bersifat merdeka. Mahkamah Konstitusi bukanlah subordinat dari Pengadilan Tata Usaha Negara, sebaliknya juga Pengadilan Tata Usaha Negara bukanlah subordinat dari Mahkamah Konstitusi.

Pada konteks inilah yang menjadi masalah. Apabila menjalankan putusan Mahkamah Konstitusi akan bertentangan dengan putusan Pengadilan Tata Usaha Negara. Sebaliknya apabila menjalankan putusan Pengadilan Tata Usaha Negara akan bertentangkan dengan putusan Mahkamah Konstitusi. Lantas putusan mana yang harus dianut apabila dua-duanya putusan secara hukum sah dan mengikat para pihak? Ini yang menjadi persoalan serius.

\section{B. Rekonstruksi Penyelesaian Sengketa Administrasi dan Hasil Pemilihan Gubernur, Bupati dan Walikota}

\section{Menyusun ulang tahapan pemilihan}

Tahapan pemilihan merupakan rangkaian kegiatan pemilihan dari awal hingga akhir pemilihan. Dalam tahapan diatur kegiatan apa saja yang akan dilaksanakan pada saat pemilihan beserta waktunya. Dapat dikatakan tahapan pemilihan merupakan perencanaan 
kegiatan pemilihan. perencanaan tersebut wajib dilaksanakan secara konsekwen untuk menjamin keadilan bagi peserta pemilihan. Dengan kata lain kegiatan pemilihan yang sudah disusun dalam tahapan pemilihan wajib dilaksanakan secara keseluruhan serta tepat waktu.

UU No. 32 Tahun 2004 tidak mengatur kapan Pemilukada harus mulai dilaksanakan. Bataswaktumulainya Pemilukada diaturdalam peraturan delegasi UU No. 32 Tahun 2004 yakni PP No. 6 tahun 2005. Pemberitahuan sisa berakhirnya jabatan kepala daerah dan wakil kepala daerah dari DPRD dijadikan sebagai batasan waktu Pemilukada resmi dimulai yang ditandai dengan KPU Provinsi atau KPU Kabupaten/Kota menetapkan tahapan dan jadwal Pemilukada. Batasan waktunya adalah 5 bulan sebelum berakhirnya masa jabatan kepala daerah dan wakil kepala daerah. ${ }^{20}$

Apabila mengacu pada pengaturan tahapan Pemilukada tersebut, jangka waktu pelaksanaan Pemilukada hanya sekitar 4 bulan saja. Sebab menurut ketentuan Pasal 86 ayat (1) UU No. 32 Tahun 2004, jadwal pemungutan suara sudah harus dilaksanakan paling lambat 1 bulan sebelum masa jabatan kepala daerah dan wakil kepala daerah. Jangka waktu pelaksanaan Pemilukada yang pendek tersebut memaksa KPU Provinsi dan KPU Kabupaten/Kota menyusun tahapan dan jadwal Pemilukada secara padat. Pelaksanaan Pemilukada yang hanya sekitar 4 bulan tentu tidaklah realistis. Meskipun masih bisa dilaksanakan, dengan tahapan yang hanya 4 bulan menyulitkan penyelenggara Pemilu untuk menyelesaian sengketa yang muncul dalam tahapan Pemilu. Padahal setiap tahapan Pemilu memilik potensi sengketa yang tidak dapat dihindari, baik sengketa antara peserta Pemilu dengan peserta Pemilu, sengketa peserta Pemilu dengan KPU maupun sengketa antara pemilih dengan KPU.

UU No. 1 Tahun 2015 yang menggantikan UU No. 32 Tahun 2004 tidak mengatur kapan tahapan pemilihan harus dimulai. Artinya kewenangan penetapan tahapan pemilihan gubernur, bupati dan walikota diserahkan kepada KPU RI sebagai komisi Negara yang mempunyai wewenang untuk menyusun dan menetapkan peraturan delegasi UU No. 1 Tahun 2015. Tahapan yang disusun oleh KPU pusat haruslah mengakomodasi potensi sengketa yang bisa saja muncul dalam setiap tahapan. Hemat penulis tahapan yang baik adalah tahapan yang memberikan kesempatan penyelesaian sengketa dalam tahapan tertentu tidak melewati tahapan yang lain. Sehingga ketika tahapan pemilihan sudah selesai maka seluruh sengketa pemilihan yang muncul juga sudah selesai.

Berikut adalah pokok-pokok tahapan Pemilihan Gubernur, Bupati dan Walikota berdasarkan UU No 1 Tahun 2015: 
Tabel 1. Pokok-pokok Tahapan Pemilihan Gubernur, Bupati dan Walikota berdasarkan UU No. 1 Tahun 2015

\begin{tabular}{|c|c|c|}
\hline Tahapan & Waktu & Keterangan \\
\hline $\begin{array}{l}\text { Penetapan Tahapan } \\
\text { Pemilihan }\end{array}$ & $\begin{array}{l}\text { Tidak diatur kapan } \\
\text { harus ditetapkan }\end{array}$ & $\begin{array}{l}\text { Tidak dirumuskan lembaga mana yang menangai } \\
\text { sengketa apabila ada perselisihan tahapan }\end{array}$ \\
\hline $\begin{array}{l}\text { Penetapan badan ad } \\
\text { hoc }\end{array}$ & $\begin{array}{l}6 \text { bulan sebelum hari } \\
\text { pemungutan suara }\end{array}$ & Termasuk sengketa Tata Usaha Negara \\
\hline $\begin{array}{l}\text { Penetapan Daftar } \\
\text { Pemilih }\end{array}$ & $\begin{array}{l}\text { Paling lambat } 30 \text { hari } \\
\text { sebelum tanggal pemu- } \\
\text { ngutan suara pemilihan }\end{array}$ & $\begin{array}{l}\text { Tidak dirumuskan lembaga mana yang menangai } \\
\text { sengketa apabila ada perselisihan penetapan daftar } \\
\text { pemilih. Namun Bawaslu Prov/Panwaslu Kab/ } \\
\text { Kota memiliki wewenang untuk menyelesaikan } \\
\text { sengketa pemilihan baik antar peserta pemilihan } \\
\text { maupun peserta pemilihan dengan penyelenggara } \\
\text { pemilihan dalam jangka waktu } 12 \text { hari }\end{array}$ \\
\hline $\begin{array}{l}\text { Penetapan pasangan } \\
\text { calon sebagai peser- } \\
\text { ta pemilihan }\end{array}$ & $\begin{array}{l}\text { Tidak diatur kapan } \\
\text { waktu harus ditetapkan }\end{array}$ & $\begin{array}{l}\text { Termasuk sengketa Tata Usaha Negara. Waktu } \\
\text { yang dibutuhkan untuk penyelesaian sengketa } \\
\text { sampai tingkat kasasi sekitar } 64 \text { hari. Namun } 64 \\
\text { hari tersebut belum termasuk waktu untuk upaya } \\
\text { administratif di Bawaslu Prov/Panwaslu Kab/Kota }\end{array}$ \\
\hline $\begin{array}{l}\text { Penetapan zona dan } \\
\text { tanggal kampanye }\end{array}$ & $\begin{array}{l}\text { Tidak diatur kapan } \\
\text { waktu harus ditetapkan }\end{array}$ & $\begin{array}{l}\text { Tidak dirumuskan lembaga mana yang menangai } \\
\text { sengketa apabila ada perselisihan penetapan daftar } \\
\text { pemilih. Namun Bawaslu Prov/Panwaslu Kab/ } \\
\text { Kota memiliki wewenang untuk menyelesaikan } \\
\text { sengketa pemilihan baik antar peserta pemilihan } \\
\text { maupun peserta pemilihan dengan penyelenggara } \\
\text { pemilihan dalam jangka waktu } 12 \text { hari }\end{array}$ \\
\hline $\begin{array}{l}\text { Pembatalan pas- } \\
\text { angan calon sebagai } \\
\text { peserta pemilihan } \\
\text { akibat melanggar } \\
\text { larangan dana kam- } \\
\text { panye }\end{array}$ & $\begin{array}{l}\text { Pada saat tahapan pel- } \\
\text { aporan dana kampanye }\end{array}$ & $\begin{array}{l}\text { Termasuk sengketa Tata Usaha Negara. Waktu } \\
\text { yang dibutuhkan untuk penyelesaian sengketa } \\
\text { sampai tingkat kasasi sekitar } 64 \text { hari. Namun } 64 \\
\text { hari tersebut belum termasuk waktu untuk upaya } \\
\text { administratif di Bawaslu Prov/Panwaslu Kab/Kota }\end{array}$ \\
\hline $\begin{array}{l}\text { Pencetakan surat } \\
\text { suara }\end{array}$ & $\begin{array}{l}\text { Tidak diatur kapan } \\
\text { waktu harus dicetak }\end{array}$ & - \\
\hline Pemungutan suara & $\begin{array}{l}\text { Tidak diatur kapan } \\
\text { harus ditetapkan }\end{array}$ & $\begin{array}{l}\text { Tidak diatur lembaga mana yang berwenang } \\
\text { menyelesaikan apabila terjadi sengketa }\end{array}$ \\
\hline $\begin{array}{l}\text { Penetapan rekapit- } \\
\text { ulasi hasil Pemilu- } \\
\text { kada dan penetapan } \\
\text { pasangan calon } \\
\text { terpilih }\end{array}$ & $\begin{array}{l}\text { Tidak ditentukan } \\
\text { dengan pasti kapan } \\
\text { pelaksanaannya }\end{array}$ & - \\
\hline $\begin{array}{l}\text { Perselisihan hasil } \\
\text { Pemilihan }\end{array}$ & $\begin{array}{l}\text { Pengajuan } 3 \text { hari ke } \\
\text { Pengadilan Tinggi } \\
\text { setelah penetapan hasil. } \\
\text { Sidang di PT } 14 \text { hari. } \\
\text { Kasasi } 14 \text { hari }\end{array}$ & - \\
\hline
\end{tabular}


Meskipun UU No. 1 Tahun 2015 tidak mengatur jadwal tahapan dengan rinci, gambaran desain tahapan pemilihan gubernur, bupati dan walikota sudah dapat dilihat. UU No. 1 Tahun 2015 mendesain tahapan pemilihan gubernur, bupati dan walikota lebih lama dan panjang daripada tahapan yang diatur dalam UU sebelumnya. Misalnya ada tahapan uji publik sebelum masa pendaftaran calon, penyelesaian sengketa Tata Usaha Negara yang masih terlampau lama, adanya kesempatan untuk membatalkan pasangan calon yang sudah ditetapkan sebagai peserta pemilihan akibat melanggar ketentuan pelaporan dana kampanye, dan seterusnya.

Pada konteks penyelesaian sengketa, tidak adanya batasan kapan harus selesai upaya administratif sengketa Tata Usaha Negara di Bawaslu Prov/Panwaslu Kab/Kota dapat berdampak penyelesaian sengketa berlaut-larut. Apabila mengacu pada klausul bahwa Bawaslu Prov/Panwaslu Kab/Kota memiliki wewenang untuk menyelesaikan sengketa pemilihan baik antar peserta pemilihan maupun peserta pemilihan dengan penyelenggara pemilihan, maka upaya administratif tersebut harus diselesaikan dalam jangka waktu 12 hari. Dengan catatan bahwa klausul Bawaslu Prov/Panwaslu Kab/Kota memiliki wewenang untuk menyelesaikan sengketa pemilihan dapat dimaknai termasuk di dalamnya sengketa Tata Usaha Negara.

Berikut adalah konstruksi baru pokokpokok tahapan dalam pemilihan yang ditawarkan oleh penulis: (lihat Tabel 2.)

\section{Penyelesaian sengketa administrasi pemilihan}

Adanya ruang pengaduan terhadap pelanggaran hukum Pemilu serta sarana penyelesaiannya merupakan ciri pelaksanaan Pemilu yang berkeadilan. ${ }^{21}$ Bahkan International Institute for Democracy and Electoral Assistance (IDEA) menyebut adanya ruang untuk menyampaikan pengaduan Pemilu dan penegakan hukum Pemilu (compliance and enforcement of electoral law) merupakan standar pelaksanaan Pemilu secara demokratis. ${ }^{22}$ Publik dapat melakukan kontrol terhadap pelaksanaan Pemilu apakah sudah sesuai dengan peraturan perundangundangan atau tidak.

Perhimpunan Pemilu untuk Demokrasi (Perludem) merumuskan 10 pedoman untuk Pemilu yang baik sebagai berikut:23

1. Adanya mekanisme dan penyelesaian hukum yang efektif;

2. Adanya aturan mengenai hukuman untuk pelanggaran Pemilu;

3. Adanya ketentuan terperinci dan memadai untuk melindungi hak pilih;

4. Adanya hak bagi pemilih, kandidat, dan parpol untuk mengadu kepada lembaga

21 International Institute for Democracy and Electoral Assistance, Keadilan Pemilu, Ringkasan Buku Acuan International IDEA, Indonesia Printer, Jakarta, 2010, hlm. 5.

22 Ramlan Surbakti, dkk, Penanganan Sengketa Pemilu, Kemitraan Bagi Pembarahuruan Tata Pemerintahan, Jakarta, 2011, hlm. 2.

23 Titi Angraini, dkk Op.cit., hlm. 73-74. 
Tabel 2. Konstruksi Baru Pokok-pokok Tahapan dalam Pemilihan

\begin{tabular}{|c|c|c|}
\hline Tahapan & Waktu & Keterangan \\
\hline $\begin{array}{l}\text { Penetapan Tahapan } \\
\text { Pemilihan }\end{array}$ & $\begin{array}{l}8 \text { bulan sebelum hari/tanggal } \\
\text { pemungutan suara }\end{array}$ & $\begin{array}{l}\text { Penanganan sengketa tahapan paling } \\
\text { lama } 10 \text { hari di Bawaslu Prov/Pan- } \\
\text { waslu Kab/Kota }\end{array}$ \\
\hline $\begin{array}{l}\text { Penetapan badan ad } \\
\text { hoc }\end{array}$ & $\begin{array}{l}\text { Paling lambat } 210 \text { hari sebelum } \\
\text { hari/tanggal pemungutan suara }\end{array}$ & $\begin{array}{l}\text { Penanganan sengketa penetapan } \\
\text { badan ad hoc di Bawaslu Prov/Pan- } \\
\text { waslu Kab/Kota paling lama } 10 \text { hari } \\
\text { dan di PTTUN selama } 20 \text { hari.Tidak } \\
\text { ada kasasi. }\end{array}$ \\
\hline $\begin{array}{l}\text { Penetapan Daftar } \\
\text { Pemilih }\end{array}$ & $\begin{array}{l}\text { Paling lambat } 60 \text { hari sebelum } \\
\text { hari/tanggal pemungutan suara }\end{array}$ & $\begin{array}{l}\text { Penanganan sengketa penetapan daft- } \\
\text { ar pemilih di Bawaslu Prov/Panwaslu } \\
\text { Kab/Kota paling lama } 10 \text { hari dan di } \\
\text { PTTUN selama } 20 \text { hari. Tidak ada } \\
\text { kasasi. }\end{array}$ \\
\hline $\begin{array}{l}\text { Penetapan pasangan } \\
\text { calon sebagai peserta } \\
\text { pemilihan }\end{array}$ & $\begin{array}{l}\text { Paling lambat } 90 \text { hari sebelum } \\
\text { hari/tanggal pemungutan suara }\end{array}$ & $\begin{array}{l}\text { Penanganan sengketa penetapan } \\
\text { pasangan calon peserta Pemilukada } \\
\text { di Bawaslu Prov/Panwaslu Kab/Kota } \\
\text { paling lama } 10 \text { hari dan di PTTUN } \\
\text { selama } 20 \text { hari. Kasasi } 14 \text { Hari. }\end{array}$ \\
\hline $\begin{array}{l}\text { Penetapan zona dan } \\
\text { tanggal kampanye }\end{array}$ & $\begin{array}{l}\text { Paling lambat } 30 \text { hari sebelum } \\
\text { hari/tanggal pemungutan suara }\end{array}$ & $\begin{array}{l}\text { Penanganan sengketa penetapan zona } \\
\text { dan tanggal kampanye di Bawaslu } \\
\text { Prov/Panwaslu Kab/Kota paling lama } \\
10 \text { hari. Putusan final mengikat }\end{array}$ \\
\hline $\begin{array}{l}\text { Pembatalan pasangan } \\
\text { calon sebagai peserta } \\
\text { pemilihan akibat me- } \\
\text { langgar larangan dana } \\
\text { kampanye }\end{array}$ & $\begin{array}{l}\text { Paling lambat } 60 \text { hari sebelum } \\
\text { hari/tanggal pemungutan suara }\end{array}$ & $\begin{array}{l}\text { Penanganan sengketa pembatalan } \\
\text { penetapan pasangan calon peserta } \\
\text { pemilihan di Bawaslu Prov/Panwaslu } \\
\text { Kab/Kota paling lama } 10 \text { hari dan di } \\
\text { PTTUN selama } 20 \text { hari. Kasasi } 14 \\
\text { Hari. }\end{array}$ \\
\hline $\begin{array}{l}\text { Pencetakan surat } \\
\text { suara }\end{array}$ & $\begin{array}{l}\text { Paling lambat } 25 \text { hari sebelum } \\
\text { hari/tanggal pemungutan suara }\end{array}$ & - \\
\hline Pemungutan suara & $\begin{array}{l}\text { Paling lambat } 2 \text { bulan sebelum } \\
\text { masa jabatan kepala daerah dan } \\
\text { wakil kepala daerah habis }\end{array}$ & - \\
\hline $\begin{array}{l}\text { Penetapan rekapitu- } \\
\text { lasi hasil Pemilukada } \\
\text { dan penetapan pas- } \\
\text { angan calon terpilih }\end{array}$ & $\begin{array}{l}7 \text { hari setelah hari/tanggal pe- } \\
\text { mungutan suara untuk pemilihan } \\
\text { bupati dan walikota dan } 14 \text { hari } \\
\text { untuk pemilihan gubernur }\end{array}$ & - \\
\hline $\begin{array}{l}\text { Perselisihan hasil } \\
\text { pemilihan }\end{array}$ & $\begin{array}{l}\text { Pengajuan } 3 \text { hari setelah peneta- } \\
\text { pan rekapitulasi hasil pemilihan } \\
\text { dan penetapan pasangan calon } \\
\text { terpilih dan sidang dilaksanakan } \\
\text { paling lama } 14 \text { hari di PTTUN } \\
\text { dan Kasasi } 14 \text { hari }\end{array}$ & - \\
\hline
\end{tabular}


penyelenggara Pemilu atau lembaga pengadilan;

5. Adanya keputusan untuk mencegah hilangnya hak pilih dari lembaga penyelenggara Pemilu atau lembaga pengadilan;

6. Adanya hak untuk banding;

7. Adanya keputusan yang sesegera mungkin;

8. Adanya aturan mengenai waktu yang dibutuhkan untuk memutuskan gugatan;

9. Adanya kejelasan mengenai implikasi bagi pelanggaran aturan Pemilu terhadap hasil Pemilu;

10. Adanya proses, prosedur, dan penuntutan yang menghargai hak asasi manusia.

Baik IDEA maupun Perludem sepakat bahwa mekanisme penyelesaian pengaduan pelanggaran Pemilu harus diselesaikan secara efektif dan cepat. Penyelesaian pengaduan pelanggaran Pemilu dilaksanakan oleh sebuah lembaga yang tepat yang dengan segera dapat memberikan kepastian hukum terhadap pengaduan. Pandangan ini membuat penyelesaian sebuah sengketa Pemilu tidak bisa disamakan dengan penyelesaian sengketa non Pemilu. Penyelesaian sengketa Pemilu membutuhkan perlakuan-perlakuan khusus agar sengketa yang timbul dapat segera selesai.

Pandangan ini dapat kita tarik pada konteks penyelesaian sengketa administrasi pemilihan gubernur, bupati dan walikota. Desain yang dibangun dalam penyelesaian sengketa pemilihan gubernur, bupati dan walikota adalah menyelesaikan dengan sesegera mungkin sengketa untuk mendapatkan kepastian hukum. Penyelesaian sengketa harus didesain berbasis pada tahapan pemilihan di mana setiap sengketa dalam tahapan tertentu yang muncul sudah harus selesai sebelum tahapan lain berjalan.

Pemilihan gubernur, bupati dan walikota merupakan kegiatan khusus yang penyelesaian sengketanya membutuhkan cara-cara khusus, cepat, ditangani oleh pihak yang memahami pemilihan serta putusannya bersifat mengikat. Oleh karena itu menurut penulis tepat untuk memberikan wewenang kepada Bawaslu provinsi dan Panwaslu kabupaten/kota untuk menyelesaikan sengketa administrasi pemilihan gubernur, bupati dan walikota pada tingkat masing-masing. Seluruh sengketa administrasi yang diputuskan oleh Bawaslu Provinsi pada penyelenggaraan pemilihan gubernur dan Panwaslu Kabupaten/Kota pada penyelenggaraan pemilihan bupati/walikota bersifat final dan mengikat kecuali untuk sengketa administrasi yang lahir dari adanya Keputusan Tata Usaha Negara. Dengan begitu tidak semua sengketa administrasi pemilihan gubernur, bupati dan walikota bermuara ke pengadilan.

Jimly Ashiddiqie ${ }^{24}$ mengatakan, pemberian wewenang untuk memeriksa dan memutus suatu perselisihan atau sengketa kepada lembaga Negara di luar lembaga peradilan yang putusannya bersifat final dan

24 Roejito dan Titik Ariyati Winahyu (ed), Op.cit., hlm.13. 
mengikat (final and biding) dimaksudkan untuk memberikan rasa keadilan bagi para pihak. Pemberian wewenang kepada lembaga Negara di luar peradilan untuk menyelesaikan sengketa menurut Jimly Ashiddiqie diakibatkan semakin kompleksnya permasalahan hukum yang membutuhkan difusi $^{25}$ kewenangan mengadili atau menyelesaikan sengketa. Bahkan di Negara yang menganut tradisi hukum common law seperti Inggris dan Amerika, penyelesaian sengketa administrasi cukup dilakukan oleh lembaga eksekutif sendiri dengan membentuk badan kuasi peradilan.

Pemikiran untuk memberikan wewenang kepada Bawaslu Provinsi/Panwaslu Kabupaten/Kota untuk memiliki wewenang menyelesaikan sengketa administrasi yang putusannya bersifat final dan mengikat di luar sengketa yang mengandung unsur tata usaha Negara diakomodir UU No. 1 Tahun 2015 dalam Pasal 143. Menurut pasal tersebut Bawaslu Provinsi dan Panwaslu Kabupaten/Kota memiliki wewenang untuk menyelesaikan sengketa pemilihan yang mencakup sengketa antar peserta pemilihan maupun sengketa antara peserta pemilihan dengan penyelenggara pemihan dalam tempo waktu 12 hari. Pasal 144 mengatur putusan
Bawaslu Provinsi dan Panwaslu Kabupaten/ Kota bersifat terakhir (final) dan mengikat. Namun untuk sengketa pemilihan yang mengundur unsur tata usaha negara, wewenang Bawaslu Provinsi dan Panwaslu Kabupaten/ Kota adalah sebagai badan penyelesai di tingkat upaya admistratif yang keputusannya masih bisa dimohonkan gugatan ke PTTUN. ${ }^{26}$

Lantas bagaimana dengan sengketa administrasi yang memenuhi unsur sengketa tata usaha negara?

Banyak pakar mengatakan eksistensi Peradilan Tata Usaha Negara penting dalam negara hukum. ${ }^{27}$ Keberadaannya menjamin setiap tindakan alat-alat Negara dapat dipertanggungjawabkan secara hukum untuk mewujudkan kesejahteraan rakyat seluasluasnya (bonnum commune), ${ }^{28}$ tak terkecuali Keputusan Komisi Pemilihan Umum Provinsi maupun Komisi Pemilihan Umum Kabupaten/ kota dalam penyelenggaraan Pemilukada. Fungsi Peradilan Tata Usaha Negara adalah sebagai tempat untuk menyelesaikan sengketa antara badan atau Pejabat Tata Usaha Negara dengan warga masyarakat (orang atau badan hukum perdata) yang merasa dirugikan akibat dikeluarkan maupun tidak dikeluarkannya keputusan tata usaha Negara. ${ }^{29}$

Dalam menyelenggarakan pemilihan

25 Difusi menurut Jimly Ashiddiqie adalah fungsi-fungsi mengadili tersebar di banyak institusi sehingga semua masalah tidak diselesaikan oleh lembaga peradilan secara konvensional. Roejito dan Titik Ariyati Winahyu (ed), 2013, Op.cit., hlm. 26.

26 Pasal 154 ayat (1) dan ayat (2) UU No. 1 Tahun 2015.

27 Jimly Ashiddiqie, Konstitusi dan Konstitusionalisme Indonesia, MKRI-PSHTN FH UI, Jakarta, 2004, hlm. 123-129.

28 Khoirul Huda, Pertanggungjawaban Hukum Penyelenggaraan Pemerintahan dalam Maladministrasi, Disertasi Program Studi Doktor Ilmu Hukum Universtas Brawijaya, 2013, Tidak dipublikasikan, hlm. 104.

29 Baca konsideran menimbang huruf $\mathrm{c}$ dan d UU. No 5 Tahun 1986 tentang Peradilan Tata Usaha Negara. 
gubernur, bupati dan walikota, Komisi Pemilihan Umum Provinsi maupun Komisi Pemilihan Umum Kabupaten/Kota mengeluarkan dua jenis keputusan. Pertama, keputusan dalam proses pemilihan. Kedua, keputusan terkait hasil pemilihan. Keputusan dalam proses pemilihan adalah keputusan yang dikeluarkan oleh Komisi Pemilihan Umum Provinsi atau Komisi Pemilihan Umum Kabupaten/Kota sejak dimulainya tahapan pemilihan sampai dengan tahapan pemungutan suara. Dengan bahasa yang lebih sederhana, Keputusan dalam proses pemilihan adalah seluruh jenis keputusan Komisi Pemilihan Umum Provinsi atau Komisi Pemilihan Umum Kabupaten/Kota dalam penyelenggaraan pemilihan di luar keputusan terkait hasil pemilihan. Sedangkan keputusan terkait hasil pemilihan adalah keputusan Komisi Pemilihan Umum Provinsi atau Komisi Pemilihan Umum Kabupaten/ Kota tentang hasil perolehan suara untuk tiap-tiap pasangan calon dalam pemilihan gubernur, bupati dan walikota.

UU No. 5 Tahun 1986 mengkategorikan keputusan Komisi Pemilihan Umum Provinsi atau Komisi Pemilihan Umum Kabupaten/ Kota terkait hasil Pemilu bukanlah objek sengketa tata usaha Negara. Sebagai bagian dari Pemilu (baca: sebelum adanya Putusan Mahkamah Konstitusi Nomor 97/ PUU-XI/2013 yang diucapkan pada tanggal 19 Mei 2014), keputusan keputusan Komisi
Pemilihan Umum Provinsi atau Komisi Pemilihan Umum Kabupaten/Kota terkait hasil pemilihan kepala daerah dan wakil kepala daerah secara langsung memenuhi unsur sebagai keputusan tata usaha Negara yang dikecualikan sebagai objek sengketa tata usaha Negara. Peradilan Tata Usaha Negara tidak memiliki wewenang untuk menyelesaikan sengketa yang muncul akibat dikeluarkannya keputusan Komisi Pemilihan Umum Provinsi atau Komisi Pemilihan Umum Kabupaten/ Kota terkait hasil pemilihan kepala daerah dan wakil kepala daerah secara langsung. Di luar keputusan Komisi Pemilihan Umum Provinsi atau Komisi Pemilihan Umum Kabupaten/ Kota terkait hasil pemilihan kepala daerah dan wakil kepala daerah secara langsung yang memenuhi unsur keputusan tata usaha Negara, Peradilan Tata Usaha Negara memiliki wewenang untuk menyelesaikan sengketanya. ${ }^{30}$

Kelemahan mendasar dimilikinya wewenang Peradilan Tata Usaha Negara untuk menyelesaikan sengketa tata usaha Negara Pemilukada adalah tidak adanya hukum acara khusus yang mengatur jalannya proses persidangan. Padahal pemilihan kepala daerah dan wakil kepala daerah memiliki tahapan yang dibatasi waktu. Hukum acara khusus penyelesaian sengketa tata usaha Negara dalam penyelenggaraan pemilihan kepala daerah dan wakil kepala daerah dapat diatur dalam perubahan UU Peradilan Tata

30 Putusan Kasasi Mahkamah Agung Nomor Nomor 14 K/TUN/2012 dalam Pemilukada Kota Depok. 
Usaha Negara atau diatur secara khusus dalam UU pemilihan kepala daerah dan wakil kepala daerah. Hukum acara khusus tersebut harus menjamin penyelesaian sengketa tata usaha Negara dalam penyelenggaraan Pemilukada berjalan dengan cepat dan memberikan rasa keadilan pada masyarakat.

Kecepatan pemeriksaan di persidangan penyelesaian sengketa tata usaha Negara dalam penyelenggaraan Pemilukada harus memperhatikan hal-hal sebagai berikut:

1. Tanpa harus mengurangi keakuratan hakim dalam menggali fakta-fakta untuk memperkuat keyakinan dalam menyusun putusan;

2. Jaminan putusan dapat dieksekusi/ dilaksanakan;

UU No. 1 Tahun 2015 lahir sebagai bentuk penyempurnaan sistem penyelenggaraan pemilihan gubernur, bupati dan walikota. Dengan pengalaman permasalahan hukum yang terjadi pada saat penyelesaian sengketa tata usaha negara pemilihan kepala daerah dan wakil kepala daerah selama ini, UU No. 1 Tahun 2015 mengatur secara khusus limitasi waktu penyelesaian sengketa tata usaha negara dalam penyelenggaraan pemilihan gubernur, bupati dan walikota. UU No. 1 Tahun 2015 ingin memberikan jaminan putusan Peradilan Tata Usaha Negara dapat dieksekusi. Hal tersebut sejalan dengan konsepsi Negara hukum Jimly Ahsiddiqie di mana jaminan dari Negara akan dilaksanakannya suatu putusan Peradilan Tata Usaha Negara oleh badan atau pejabat tata usaha Negara mutlak dibutuhkan.
Limitasi waktu penyelesaian sengketa tata usaha negara dalam penyelenggaraan pemilihan gubernur, bupati dan walikota sebagaimana diatur UU No. 1 Tahun 2015 membutuhkan singkronisaisi dengan tahapan yang lain. Tanpa itu, jaminan akan dapat dieksekusinya putusan Peradilan Tata Usaha Negara sulit dilakukan. Misalnya ketentuan waktu penyelesaian sengketa tata usaha negara haruslah diikuti dengan perumusan waktu tahapan pemungutan suara setelah putusan sengketa tata usaha negara memiliki kekuatan hukum tetap.

\section{Penyelesaian sengketa hasil pemilihan}

Salah satu pertimbangan Mahkamah Konstitusi mengabulkan permohonan uji materiil Pasal 236C UU No. 12 Tahun 2008 yang mengatur peralihan penanganan perselisihan hasil pemilihan kepala daerah dan wakil kepala daerah dari Mahkamah Agung kepada Mahkamah Konstitusi adalah adanya pembatasan (limitation) kewenangan Mahkamah Konstitusi yang diatur dalam UUD 1945. Pembatasan kewenangan tersebut haruslah dimaknai bahwa tidak ada penambahan kewenangan Mahkamah Konstitusi terkecuali diatur dalam UUD 1945. Penambahan kewenangan Mahkamah Konstitusi yang diatur di luar UUD 1945 termasuk oleh UU bertentangan dengan UUD 1945. Melalui argument tersebut Mahkamah Konstitusi menyatakan tidak memiliki kewenangan untuk menyelesaikan 
perselisihan hasil pemilihan kepala daerah dan wakil kepala daerah. ${ }^{31}$

Dampak adanya Putusan Mahkamah Konstitusi yang menyatakan tidak memiliki kewenangan menyelesaikan perselisihan hasil pemilihan kepala daerah dan wakil kepala daerah mengharuskan adanya desain baru penyelesaian sengketa hasil pemilihan kepala daerah dan wakil kepala daerah. Harifin A Tumpa memberikan dua alternatif model penyelesaian sengketa hasil pemilihan kepala daerah dan wakil kepala daerah. Sebagai bagian dari sengketa keperdataan, sengketa perselisihan hasil pemilihan kepala daerah dan wakil kepala daerah hanya dapat diselesaikan oleh pihak ketiga. Dalam praktek pihak ketiga yang dapat menyelesaikan suatu sengketa adalah lembaga yudikatif (MA beserta jajarannya dan MK) serta lembaga perwasitan atau arbitrase. Lembaga yudikatif dalam menyelesaikan sengketa wewenangnya diberikan oleh UU. Sedangkan lembaga arbitrase yang ditunjuk sebagai lembaga penyelesaian sengketa didasarkan pada kesepakatan para pihak yang bersengketa. ${ }^{32}$

Penulis tidak sependapat dengan argumentasi Harifin A Tumpa yang mengkategorikan sengketa hasil pemilihan kepala daerah dan wakil kepala daerah termasuk sengketa keperdataan. Menurut hemat peneliti, pemilihan kepala daerah dan wakil kepala daerah adalah ranah publik, bukan privat. Pemilihan kepala daerah dan wakil kepala daerah tidak hanya melibatkan para pihak yang menjadi peserta pemilihan saja, tetapi juga rakyat. Proses penyelesaian sengketanya tidak bisa didasarkan hanya pada kesepakatan para pihak yang dituangkan dalam perjanjian layaknya model penyelesaian arbitrase. Sebab yang dijamin rasa keadilannya bukan hanya para pihak yang bersengketa, tetapi juga masyarakat yang nasibnya akan dipengaruhi oleh kepala daerah dan wakil kepala daerah terpilih yang memimpin mereka pada periode tertentu.

Sebagai suatu sengketa yang bersifat publik, Negara dituntut hadir sebagai pihak yang berkepentingan untuk melindungi rakyat. Negara harus berposisi sebagai pihak yang terlibat secara aktif untuk menyelesaikan sengketa hasil pemilihan kepala daerah dan wakil kepala daerah. Caranya adalah dengan membentuk regulasi yang mengatur bahwa lembaga yang menyelesaikan sengketa hasil pemilihan kepala daerah dan wakil kepala daerah adalah lembaga Negara yang kewenangannya diberikan undang-undang, bukan lembaga yang bersifat privat yang ditunjuk berdasarkan perjanjian antara para pihak tertentu.

Perselisihan hasil pemilihan kepala daerah dan wakil kepala daerah termasuk sengketa pemilihan yang memiliki skala besar. Oleh sebab itu perselisihan hasil pemilihan kepala daerah dan wakil kepala daerah harus ditangani oleh lembaga peradilan. Van Praag

31 Periksa Putusan Mahkamah Konstitusi Nomor 97/PUU-XI/2013, hlm. 53.

32 Harifin A Tumpa, Selasa 2 Juni 2014, Sengketa Pilkada, Kolom Opini Kompas, hlm. 5. 
mengemukakan Peradilan adalah penentuan berlakunya suatu peraturan hukum pada suatu peristiwa yang kongkrit bertalian dengan adanya suatu perselisihan. Di tambahkan Van Apeldoorn, peradilan adalah pemutus perselisihan oleh suatu instansi yang tidak mempunyai kepentingan dalam perkara maupun merupakan bagian dari pihak yang berselisih tetapi berdiri di atas perkara. ${ }^{33}$ Sjachran Basah menguraikan unsur-unsur peradilan sebagai berikut: ${ }^{34}$

a. Adanya aturan hukum yang dapat diterapkan pada persoalan;

b. Adanya suatu sengketa hukum yang kongkrit;

c. Adanya sekurang-kurangnya dua pihak;

d. Adanya badan peradilan yang berwenang memutuskan sengketa;

e. Adanya hukum formal dalam rangka menerapkan hukum dan menemukan hukum untuk menjamin ditaatinya hukum materiil.

Mengacu pendapat para pakar tersebut, peradilan bukanlah suatu lembaga tertentu. Peradilan adalah suatu sistem penyelesaian sengketa yang di dalamnya termasuk adanya badan peradilan yang merujuk pada lembaga yang diberikan wewenang untuk menyelesaikan sengketa tertentu. Jimly Ashiddiqie mengklasifikasikan peradilan di Indonesia menjadi tiga macam, peradilan yang disebut secara langsung oleh konstitusi yakni Mahkamah Agung dan badan peradilan di bawahnya serta Mahkamah Konstitusi, peradilan khusus dan terakhir peradilan semu/ lembaga kuasai peradilan. ${ }^{35}$

UUD 1945 menyatakan badan-badan peradilan di bawah Mahkamah Agung yang dikategorikan sebagai pelaksana kekuasaan kehakiman. ${ }^{36}$ Apabila ada peradilan khusus yang tidak berpuncak pada Mahkamah Agung berdasarkan konstitusi tidak dapat dikategorikan sebagai pelaksana kekuasaan kehakiman. Begitu halnya dengan keberadaan lembaga kuasi peradilan/peradilan semu yang kedudukannya bukan di bawah Mahkamah Agung tidak dapat dikategorikan sebagai pelaksana kekuasaan kehakiman.

Perbedaan mendasar badan peradilan yang termasuk pelaksana kekuasaan kehakiman dan yang bukan pelaksana kekuasaan kehakiman terletak pada aspek konstitusionalitasnya dan aspek strukturalnya. Kekuasaan kehakiman merupakan cabang kekuasaan yang terpisah dari cabang kekuasaan lain yang memiliki sifat merdeka dan diatur dalam konstitusi. Sedangkan pengadilan khusus dan badan peradilan semu yang bukan pelaksana kekuasaan kehakiman tidak termasuk cabang kekuasaan tersendiri dalam struktur kenegaraan dan keberadaannya tidak diatur dalam konstitusi. Bahkan beberapa

33 Jayus, Rekonseptualisasi Penyelesaian Perselisihan Hasil Pemilihan Umum di Indonesia, Disertasi Program Doktor Ilmu Hukum Universitas Brawijaya, 2013, Tidak dipublikasikan, Op.cit., hlm. 124.

34 Sjahran Basah, Eksistensi dan Tolak Ukur Badan Peradilan Administrasi Negara di Indonesia, Alumni, Bandung, 1997, hlm. 30.

35 Roejito dan Titik Ariyati Winahyu (ed), hlm. 1-2.

36 Periksa Pasal 24 Ayat (2) UUD 1945. 
di antaranya ada yang termasuk bagian dari eksekutif seperti Komisi Pengawas Persaingan Usaha serta Pengadilan Pajak yang menggunakan mekanisme dua atap, di bawah Mahkamah Agung dan Kementerian Keuangan.

Sebagai suatu sengketa pemilihan yang berskala besar dan memiliki pengaruh yang luas di masyarakat, penyelesaian sengketa hasil pemilihan kepala daerah dan wakil kepala daerah harus diselesaikan oleh badan peradilan yang merdeka dan merupakan pelaksana kekuasaan kehakiman. Penyelesaian sengketa pemilihan kepala daerah dan wakil kepala daerah tidak dapat diserahkan kepada badan peradilan semu. Sebab pada hakekatnya badan peradilan semu bukanlah badan peradilan yang memiliki kompetensi utama untuk menyelesaikan suatu sengketa.

Ada dua alternatif pilihan badan peradilan di bawah Mahkamah Agung yang dapat diberikan wewenang untuk menyelesaikan sengketa perselisihan hasil pemilihan kepala daerah dan wakil kepala daerah. Keduanya dapat diberikan wewenang secara konstitusional. Pertama, adalah Pengadilan Tinggi Tata Usaha Negara yang berada di bawah rumpun Peradilan Tata Usaha Negara. Seiring dengan adanya Putusan Mahkamah Konstitusi Nomor 97/PUU-XI/2013 yang menyatakan bahwa pemilihan kepala daerah dan wakil kepala daerah dan wakil kepala daerah bukanlah bagian dari Pemilu, maka keputusan hasil pemilihan kepala daerah dan wakil kepala daerah bukanlah termasuk keputusan yang dikecualikan sebagai keputusan tata usaha Negara sebagaimana dimaksud dalam Pasal 2 angka 7 UU No. 9 Tahun 2004. ${ }^{37}$

Keputusan hasil pemilihan kepala daerah dan wakil kepala daerah memiliki dua dimensi yakni dimensi menyangkut perolehan suara berupa rekapitulasi perolehan suara tiap-tiap pasangan calon dan dimensi menyangkut pasangan calon kepala daerah dan wakil kepala daerah yang nantinya dinyatakan terpilih. Kedua dimensi keputusan tersebut saling terkait karena hasil rekapitulasi perolehan suara pada ujungnya akan menentukan siapa pasangan calon yang diputuskan oleh Komisi Pemilihan Umum Provinsi/Kabupaten/Kota sebagai pasangan calon terpilih. Sehingga dapat disimpulkan keputusan hasil pemilihan kepala daerah dan wakil kepala daerah termasuk jenis keputusan tata usaha Negara yang memiliki sifat kongkrit, individual, final dan memiliki dampak hukum.

Kedua, adalah membentuk pengadilan khusus perselisihan hasil pemilihan kepala daerah dan wakil di bawah rumpun Peradilan Tata Usaha Negara. Pengadilan khusus ini hanya berwenang menyelesaikan sengketa hasil pemilihan kepala daerah dan wakil kepala daerah yang menyangkut rekapitulasi hasil perolehan suara dan penetapan pasangan calon terpilih. 
Dari kedua alternatif tersebut, penulis lebih memilih memberikan wewenang kepada Pengadilan Tinggi Tata Usaha Negara untuk menyelesaikan perselisihan hasil pemilihan kepala daerah dan wakil. Beberapa pertimbangan yang dapat dikemukakan adalah sebagai berikut:

1. Memaksimalkan keberadaan badan peradilan yang sudah ada sebagai bentuk penghematan anggaran Negara;

2. Menghindari adanya dualisme putusan badan peradilan yang berbeda. Menurut Yuliandri, ${ }^{38}$ sebuah sengketa yang memiliki dimensi persoalan yang sama apabila diselesaikan oleh dua badan peradilan yang berbeda memiliki dua kecenderungan dalam putusannya, yakni saling mendukung atau saling bertolak belakang. Sengketa hasil pemilihan kepala daerah dan wakil kepala daerah tidak bisa dilepaskan dari proses-proses penyelenggaraan pemilihan termasuk di dalamnya sengketa penetapan pasangan calon, sengketa daftar pemilih yang wewenang penyelesaiannya berada di Peradilan Tata Usaha Negara. Oleh sebab itu lebih tepat wewenang penyelesaiannya sekaligus diberikan kepada Peradilan Tata Usaha Negara;

3. Jangka waktu pelaksanaan pemilihan kepala daerah dan wakil kepala daerah yang lima tahun sekali. Apabila dibentuk pengadilan khusus maka beban kerjanya terlalu ringan yakni hanya pada saat ada penyelenggaraan pemilihan kepala daerah dan wakil kepala daerah;

4. Penyelesaian sengketa yang langsung ditangani oleh Pengadilan Tinggi Tata Usaha Negara yang putusannya dapat dimintakan kasasi ke Mahkamah Agung untuk menjamin proses penyelesaiannya berjalan dengan cepat sehingga tidak terjadi kekosongan kekuasaan di daerah.

Berbedadengan rumusan penulis, UUNo. 1 Tahun 2015 memilihPengadilan Tinggi sebagai pengadilan yang berwenang menyelesaikan sengketa hasil pemilihan gubernur, bupati dan walikota. Putusan Pengadilan Tinggi dapat dimintakan kasasi ke Mahkamah Agung. ${ }^{39}$ Pemberian kewenangan Penggadilan Tinggi ini berpotensi melahirkan permasalahan yang sama pada penyenggaraan pemilihan gubernur, bupati dan walikota sebelum UU No. 1 Tahun 2015 berlaku. Permasalahan tersebut adalah adanya dualisme putusan yang berbeda. Bisa saja dalam perjalanan waktu hakim Pengadilan Tinggi memperluas penafsiran sengketa hasil pemilihan gubernur, bupati dan walikota termasuk di dalamnya adalah sengketa proses pemilihan yang mempengaruhi hasil pemilihan layaknya yang dilakukan Mahkamah Konstitusi. Dengan begitu cakupan materi sengketa nantinya bisa masuk dalam ranah penetapan pasangan calon yang notabene menjadi objek sengketa Tata Usaha Negara.

38 Patmoko (ed), Dialektika Pembaruan Sistem Hukum Indonesia, Sekretariat Jenderal Komisi Yudisial Republik Indonesia, Jakarta, 2012, hlm. 66-67.

39 Pasal 157 ayat (1) UU No 1 Tahun 2015. 
Memang baik PTTUN maupun Pengadilan Tinggi sama-sama putusannya dapat dikoreksi oleh Mahkamah Agung. Sehingga dapat dimungkinkan apabila ada putusan yang berbeda antara PTTUN dengan Pengadilan Tinggi, Mahkamah Agung masih dapat melakukan perbaikan. Meskipun begitu, adanya dualisme putusan yang berbeda akan menjadi preseden buruk di dunia peradilan indonesia. RUU Perubahan UU No. 1 Tahun 2015 yang sudah disepakati Komisi II DPR RI mengubah penanganan sengketa hasil pemilihan gubernur, bupati dan walikota dari Penggadilan Tinggi ke badan peradilan khusus. Sebelum badan peradilan khusus dibentuk, penanganan sengketa hasil pemilihan gubernur, bupati dan walikota diserahkan ke Mahkamah Konstitusi. Sebagaimana yang sudah dikemukakan penulis, pembentukan badan peradilan tersendiri untuk menangani sengketa hasil pemilihan gubernur, bupati dan walikota akan memboroskan keuangan negara. Di samping itu, beban kerja peradilan tersebut tidaklah terlalu berat. Lebih baik negara memanfaatkan dan memaksimalkan keberadaan badan peradilan yang sudah ada.

\section{Simpulan}

1. Pengaturan penyelesaian sengketa administrasi dan hasil pemilihan gubernur, bupati dan walikota dalam peraturan perundang-undangan sebelum UU No. 1 Tahun 2015 berlaku telah menimbukan permasalahan hukum. Mepetnya jadwal dalam tahapan pemilihan menyebabkan terjadinya disharmonisasi hukum acara Peradilan Tata Usaha Negara dengan tahapan pemilihan. Singkatnya waktu yang dialokasikan untuk penyelesaian perselisihan hasil pemilihan berdampak terjadinya disharmonisasi hukum acara perselisihan hasil pemilihan umum kepala daerah dan wakil kepala daerah di Mahkamah Konstitusi dengan hukum acara Peradilan Tata Usaha Negara. Selanjutnya tidak bisa tereksekusinya putusan Peradilan Tata Usaha Negara yang telah berkekuatan hukum tetap yang disebabkan putusan dikeluarkan setelah seluruh tahapan pemilihan selesai dilaksanakan atau setelah kepala daerah dan wakil kepala daerah terpilih dilantik oleh Gubernur. Terakhir terjadinya ketidakpastian hukum akibat adanya dualisme putusan badan peradilan yang berbeda.

2. Konstruksi baru penyelesaian sengketa administrasi dan hasil Pemilihan Gubernur, Bupati dan Walikota adalah:

a. Tahapan pemilihan gubernur, bupati, dan walikota sebagaimana diatur dalam UU No. 1 Tahun 2015 belum terlalu rinci dan didesain dengan waktu panjang. Oleh sebab itu masih perlu untuk dilakukan pembenahan desain tahapan pemilihan yang sudah diatur dalam UU No. 1 Tahun 2015;

b. Badan Pengawas Pemilu Provinsi (pada pemilihan gubernur) dan Panitia Pengawas Pemilu Kabupaten/ 
Kota ( pada pemilihan bupati/ walikota) memiliki wewenang untuk menyelesaikan sengketa pemilihan yang putusannya bersifat final dan mengikat terkeculai untuk sengketa yang mengandung unsur tata usaha negara dengan batasan waktu penyelesaian sengketa 12 hari;

c. Pengaturan limitasi waktu penyelesaian sengketa tata usaha Negara di Peradilan TataUsaha Negara harus disertai dengan sinkronisasi jadwal tahapan pemungutan suara; d. Penunjukan Pengadilan Tinggi (UU No. 1 Tahun 2015) atau badan peradilan khusus (hasil revisi UU No. 1 Tahun 2015) sebagai lembaga yang berwenang menyelesaian perselisihan hasil pemilihan gubernur, bupati dan walikota tidak tepat. Menurut penulis, penyelesaian sengketa perselisihan hasil pemilihan gubernur, bupati dan walikota idealnya diserahkan kepada Pengadilan Tinggi Tata Usaha Negara yang putusannya dapat dimintakan kasasi ke Mahkamah Agung.

\section{DAFTAR PUSTAKA}

\section{Buku}

Achmad Dodi Hermanto (ed), 2012,

Demokrasi Lokal, Evaluasi Pemilu-

kada di Indonesia, KONpress, Jakarta.

Didik Supriyanto, dkk, 2012, Penguatan

Bawaslu, Optimalisasi Fungsi,

Organisasi dan Fungsi dalam Pemilu

2014, Perludem, Jakarta.

Chad Vuckery (ed), 2011, Pedoman untuk

Memahami, Menangani, dan

Menyelesaikan Sengketa Pemilu,

International Foundantion for Electoral

System, Amerika Serikat.

International Institute for Democracy and

Electoral Assistance, 2010, Keadilan

Pemilu, Ringkasan Buku Acuan

International IDEA, Indonesia Printer,

Jakarta.
Jayus, 2013, Rekonseptualisasi Penyelesaian

Perselisihan Hasil Pemilihan Umum

di Indonesia, Disertasi, Program

Doktor Ilmu Hukum Universitas Brawijaya.

Jimly Ashdiqqie, 2004, Konstitusi dan

Konstitusionalisme Indonesia, MKRIPSHTN FHUI, Jakarta.

Khoirul Huda, 2013, Pertanggungjawaban

Hukum Penyelenggaraan Pemerintahan dalam Maladministrasi, Disertasi, Program Studi Doktor Ilmu Hukum Universtas Brawijaya, Malang. Patmoko (ed), 2012, Dialektika Pembaruan Sistem Hukum Indonesia, Sekretariat Jenderal Komisi Yudisial Republik Indonesia. 
Peter Mahmud Marzuki, 2012, Penelitian

Hukum, Kencana Prenada Media Group, Jakarta.

Ramlan Surbakti, dkk, 2011, Penanganan

Sengketa Pemilu, Kemitraan Bagi

Pembarahuruan Tata Pemerintahan, Jakarta.

Roejito dan Titik Ariyati Winahyu (ed), 2013,

Putih Hitam Pengadilan Khusus,

Sekretariat Jenderal Komisi Yudisial, Jakarta.

Sjachran Basah, 1997, Eksistensi dan Tolak

Ukur Badan Peradilan Administrasi

Negara di Indonesia, Alumni,

Bandung.

Titi Angraini dkk, 2011, Menata Kembali

Pengaturan Pemilukada, Perludem, Jakarta.

Winarno Yudho, dkk, 2005, Mekanisme

Impeachment dan Hukum Acara Mahkamah Konstitusi, Pusat

Penelitian dang Pengkajian Sekretariat

Jenderal dan Kepaniteraan Mahkamah

Konstitusi kerjasama dengan Konrad-

Adenauer-Stiftung, Jakarta.

\section{Peraturan Perundang-undangan}

Undang-undang Nomor 22 Tahun 2009 tentang Pemerintahan Daerah.

Undang-undang Nomor 32 Tahun 2004 tentang Pemerintahan Daerah.

Undang-undang Nomor 12 Tahun 2008 tentang Perubahan UU Nomor 32 Tahun 2004 tentang Pemerintah Daerah.
Undang-undang Nomor 15 Tahun 2011 tentang Penyelenggara Pemilihan Umum.

Undang-undang Nomor 5 Tahun 1986 tentang Peradilan Tata Usaha Negara.

Undang-undang Nomor 1 Tahun 2015 tentang Penetapan Peraturan Pemerintah Pengganti Undang-undang Nomor 1 Tahun 2014 tentang Pemilihan Gubernur, Bupati dan Walikota Menjadi undang-undang.

Peraturan Pemerintah Nomor 6 Tahun 2005 tentang Pemilihan Pengesahan Pengangkatan dan Pemberhentian Kepala Daerah dan Wakil Kepala Daerah.

\section{Surat Kabar}

Harifin A Tumpa, 2 Juni 2014, Sengketa Pilkada, Kolom Opini Kompas.

\section{Putusan Pengadilan}

Putusan Mahkamah Konstitusi Nomor 75/ PUU-VIII/2010.

Putusan Mahkamah Konstitusi Nomor 97/ PUU-XI/2013.

Putusan Pengadilan Tata Usaha Negara Jayapura Nomor 14/G.TUN/2012/ PTUN.JPR.

Putusan Pengadilan Tata Usaha Negara Jayapura Nomor 01/G.TUN/2012/ PTUN.JPR.

Putusan Kasasi Mahkamah Agung Nomor 14 K.TUN/2012.

Surat Edaran Mahkamah Agung Nomor 7 Tahun 2010 tentang Petunjuk Teknis Sengketa Mengenai Pemilihan Kepala Daerah. 